\title{
RC T beams strengthened to shear with carbon fiber composites
}

\section{Vigas $T$ de concreto armado reforçadas à força cortante com compósito de fibras de carbono}

L. A. SPAGNOLO JR a spagnolojr@petrobras.com.br

E. S. SÁNCHEZ FILHO b emilsanchez@uol.com.br

M. S. L. VELASCO c marta@puc-rio.br

\begin{abstract}
This paper presents the experimental data of the behavior of reinforced concrete beams strengthened to shear with carbon fiber composites. The tests were composed of eight T beams, $b_{w}=15 \mathrm{~cm}, \mathrm{~h}=40 \mathrm{~cm}$, flange width $40 \mathrm{~cm}$, flange height $8 \mathrm{~cm}$, and length $300 \mathrm{~cm}$, divided into two series with the same longitudinal steel reinforcement and a reference beam without strengthening in each series. The beams had two types of arrangement of internal steel stirrups. The test variables were the internal and external geometric ratio of the transverse reinforcement and the mechanical ratio of carbon fiber composites stirrups. All the beams were loaded at two points. The strengthened beams were submitted to a preloading and the strengthening was applied to the cracked beam. All the beams were designed in order to guarantee shear failure, and the ultimate load of the strengthened beams was $36 \%$ to $54 \%$ greater than the reference beams. The Cracking Sliding Model applied to the strengthened beams was evaluated and showed good agreement with the experimental results.
\end{abstract}

Keywords: shear strengthening; reinforced concrete; external strengthening; carbon fiber composites.

\section{Resumo}

Este artigo apresenta os dados de ensaios de vigas de concreto armado reforçadas à força cortante com compósito de fibras de carbono. Os ensaios de oito vigas $T, b_{w}=15 \mathrm{~cm}, h=40 \mathrm{~cm}$, largura da mesa igual a $40 \mathrm{~cm}$, altura da mesa $8 \mathrm{~cm}$, comprimento de $300 \mathrm{~cm}$, divididos em duas séries com a mesma armadura longitudinal e uma viga de referência sem reforço externo para cada série. As vigas tinham dois tipos de arranjos de estribos internos de aço. As variáveis dos ensaios foram as taxas geométricas das armaduras transversais internas e externas, e a taxa mecânica da armadura em estribos de compósito de fibras de carbono. Todas as vigas foram carregadas em dois pontos. As vigas reforçadas foram submetidas a um carregamento prévio e reforçadas após a fissuração. Todas as vigas foram projetadas para garantir a ruptura por força cortante, e as forças últimas das vigas reforçadas foram de $36 \%$ a $54 \%$ superiores às das vigas de referência. O Modelo da Fissura Deslizante foi avaliado e mostrou boa concordância com os resultados experimentais.

Palavras-chave: reforço à força cortante; concreto armado; reforço externo; compósito de fibras de carbono.

a LUIS ALBERTO SPAGNOLO JR. is a Structural Engineer at Petrobras, Rio de Janeiro, Brazil. He received his M. Sc. in Structural Engineering from PUC Rio. Contact: spagnoloji@petrobras.com.br

b EMIL DE SOUZA SÁNCHEZ FILHO is an Associate Professor of Civil Engineering at the Fluminense Federal University, Niterói, Rio de Janeiro, Brazil. He is member of ACI, PCI, FIB, IABSE, IBRACON, ABPE and ABCM. He received his M. Sc. and D. Sc. in Structural Engineering from COPPE-Federal University of Rio de Janeiro. Contact: emilsanchez@uol.com.br

c MARTA DE SOUZA LIMA VELASCO is an Associate Professor of Civil Engineering at PUC-Rio. She received her M. Sc. from PUC-Rio, and her D. Sc. in Structural Engineering from COPPE-Federal University of Rio de Janeiro. 


\section{Introduction}

Concrete carbon fiber strengthening has been widely used over the last 20 years in several countries, and can be considered a well-established construction procedure. But during the last few years, important research has contributed to new design and analysis models for the strengthening system currently used by engineers ([1], [2], [3])

The technique of strengthening reinforced concrete beams with externally-bonded composite materials has been shown to be efficient. Results obtained from reports and manuals concerning the state-of-the-art of this technique indicate that the shear strengthening of reinforced concrete has some confusing and unexplained features. This is due to the fact that the composite material, glued to the concrete surface, has linear-elastic behavior, quite different to the non-linear behavior of the structural element.

The shear strengthening of reinforced concrete beams in bridges and buildings may be applied due to several causes: design, faults, increased load, functional changes, environmental attacks, etc. The mechanisms by which shear is carried out in reinforced concrete beams are very complex, and still not well understood. In general, the contribution of the shear reinforcement is calculated according to the truss analogy (steel and CFC). The shear resistance offered by con-

\section{Figure 1 - Cracking sliding model}

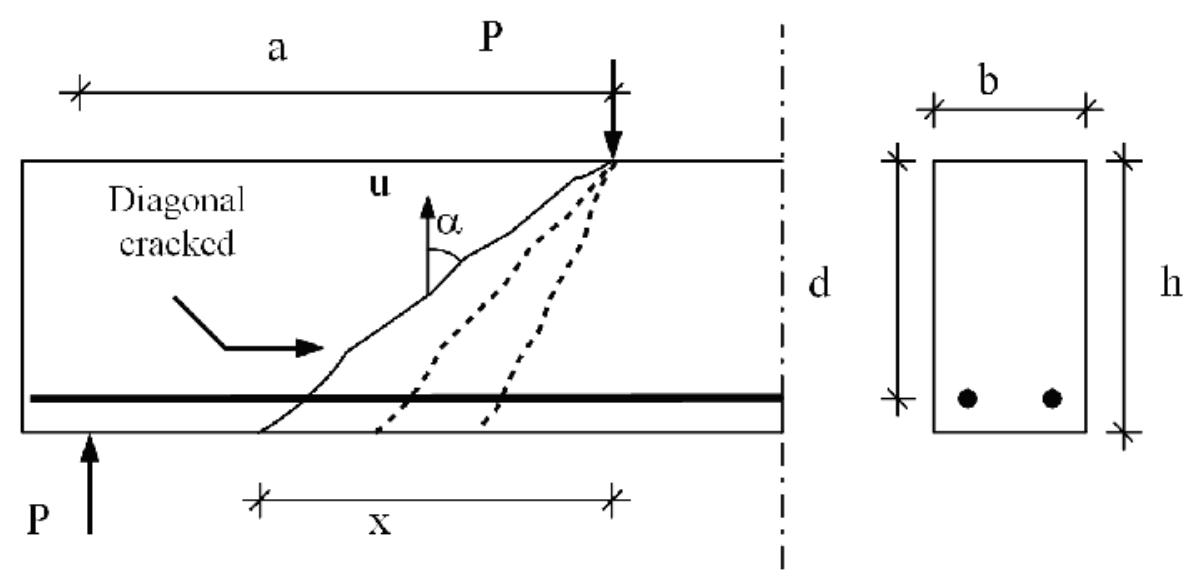

A Idealized diagonal cracks
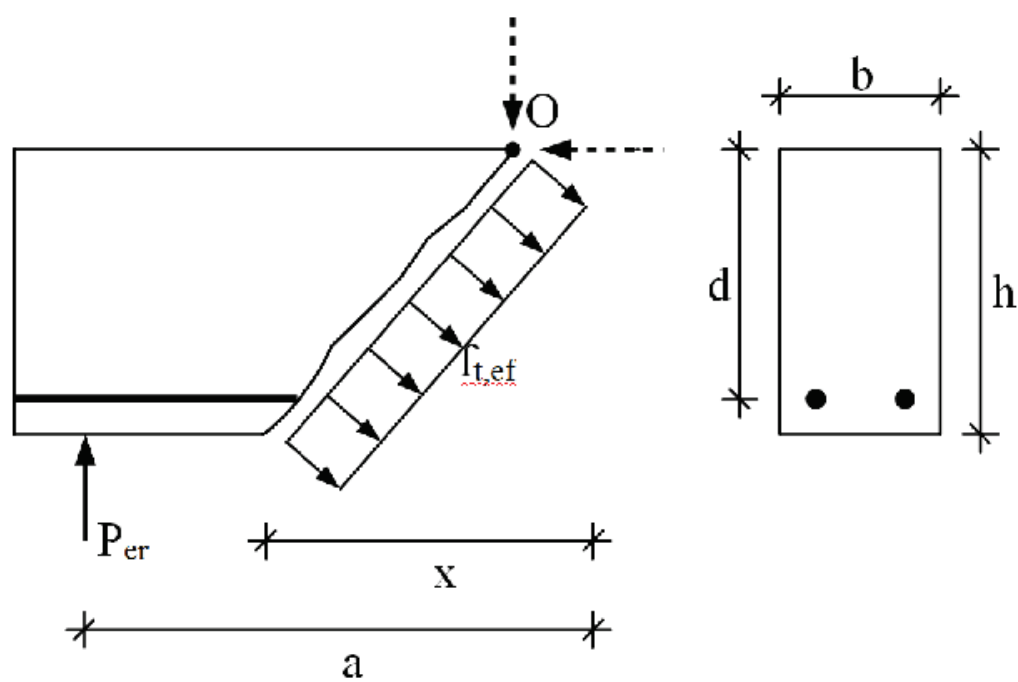
crete is given by empirical equations. Although several experiments concerning shear strengthening have been reported in the literature ([4], [5], [6], [7], [8]), few offer clear and conclusive experimental data. In this work, a more comprehensive shear experimental study was performed. This study aimed to establish new experimental and consistent data in order to evaluate the ultimate shear of the beams strengthened with $\mathbf{U}$ stirrups of carbon fiber composites.

\section{Research significance}

The objective of this study was to investigate the effectiveness behavior of RC $\mathbf{T}$ beams strengthened to shear with CFC. This paper presents an experimental program with the followings objectives: 1) to understand the effect of shear mechanism in the tested beams; 2) to corroborate a theoretical model; and 3) to supply the literature with detailed test data that can support further research in this area. The theoretical model proposed herein was assessed by comparing the calculated and measured response of eight test beams, and provided accurate numerical tools that can be exploited to understand and predict this type of strengthening.

\section{Analytical model}

Traditional standard analyses and design specifications for the shear strengthening of reinforced concrete beams use the diagonal cracking strength $V$ as an estimate of the concrete contribution, and, in general, adopt the classical truss model for calculating shear reinforcements (steel and CFC) to shear capacity.

The concrete contribution to shear resistance is far more varied because it is the sum of several internal mechanisms of resistance: shear carried in the compression zone (uncracked zone), aggregate interlock (shear friction between cracks), and dowel action. The literature furnishes several formulas for calculating the concrete contribution, and the most important codes have selected significantly different approaches for the $V_{c}$ portion.

This study seeks to investigate a suitable upper-bound solution and evaluate this model by comparison with experimental data ([9], [10], [11]).

\subsection{Upper-bound solution}

An upper-bound solution shows that failure must occur for any compatible plastic deformation if the rate of the external work of applied forces on the beam equals the rate of internal energy dissipation for all materials: concrete, steel and CFC.

In the upper-bound approach, it is necessary to hypothesize a displacement field in discontinuities between the rigid regions of the beam (these regions are rigid bodies), each with a constant displacement (or rate of displacement). The rate of internal dissipation depends on the selection of the displacement field, and it is independent of the applied loads.

The basis for this study is summarized below, followed by the proposed relationships for the upper-bound model.

For beams without shear reinforcement or lightly reinforced beams, the shear strength is determined by the Cracking Sliding Model (CSM). "This model is based on the hypothesis that cracks can be transformed into yield lines, which have lower sliding strength than yield lines formed in uncracked concrete".

For a crack transformation into a yield line, the internal work per unit length is calculated. The angle variation between the yield line and the displacement direction $\alpha$ is limited by $\varphi \leq \alpha \leq \pi-\varphi$, where $\varphi$ is the angle of friction of the concrete. This limitation on $\alpha$ shows that crack sliding must be treated as a plane strain problem.

In this upper-bound analysis of the failure mechanisms, the beams are loaded in four points divided into a series of three rigid blocks. These blocks are separated by lines of discontinuity (Figure [1]). The relationships for the shear capacity are obtained from kinematic and yield conditions, and form an upper-bound solution of Plasticity Theory for reloaded concrete beams.

The theoretical approach proposed obeys all hypotheses of the CSM, and offers some new conditions to evaluate the ultimate load of reinforced concrete beams strengthened with glued CFC vertical stirrups. The following analysis considers all formulas valid for $T$ beams. The external shear reinforcement can be evaluated in an additive way, assuming that its behavior is similar to the behavior of steel stirrups (Figure [2]). The total mechanical ratio of the trans-

\section{Figure 2 - CSM for reinforced concrete beams strengthened with glued CFC vertical stirrups}
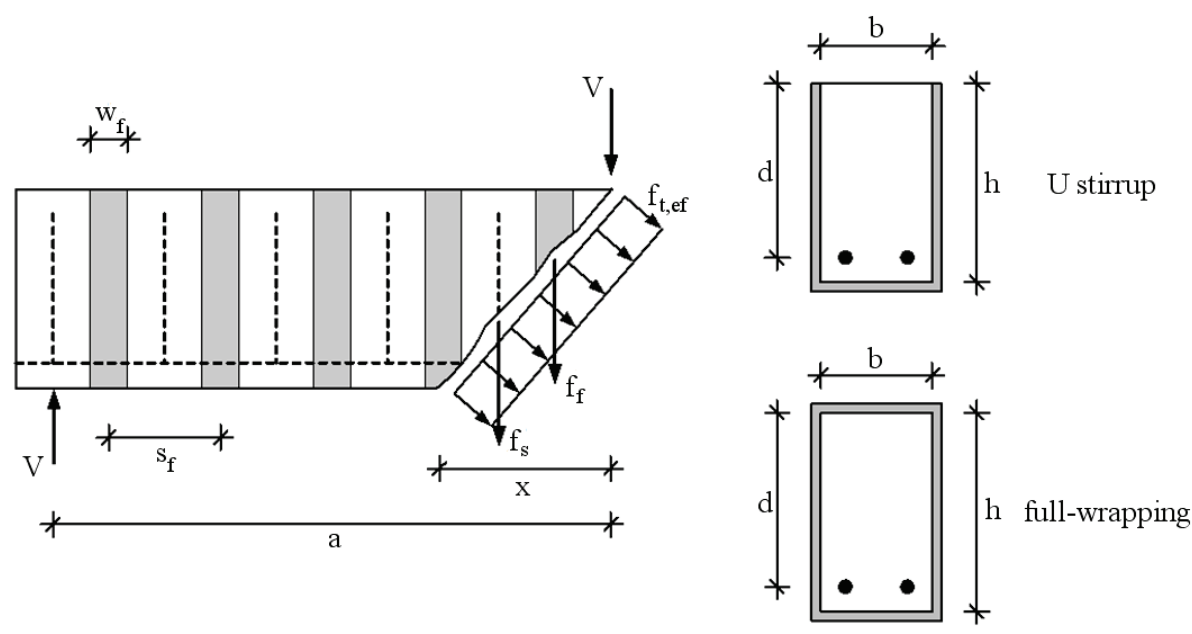
verse reinforcement can be seen as the sum of two terms ([12]).

$\omega=\omega_{s w}+\omega_{f w}$

$$
\omega_{s w}=\frac{A_{s w}}{b_{w} d} \frac{f_{y w}}{v_{0} f_{c}}
$$

$$
\omega_{f w}=\frac{2 t_{f} w_{f}}{b_{w} s_{f}} \frac{f_{u, f}}{v_{0} f_{c}}
$$

Concrete strengths of tested beams are very different to the strength measured on $15 \mathrm{~cm} \times 30 \mathrm{~cm}$ cylinder specimens because the concrete is cracked and the cracking reduces the strength. It is essential to consider a reduced concrete strength and, in the models of Plasticity Theory, it is indispensable to insert a concrete effectiveness factor $v_{0} \leq 1$ into the theoretical solution. Concrete is regarded as a perfectly plastic material, which has a brittle behavior with poor ductility in compression. The effectiveness factor $v_{0}$ decreases with the increase of the concrete compressive strength.

The effectiveness factor is given by:

$$
v_{0}=\frac{0.88}{\sqrt{f_{c}}}\left(1+\frac{1}{\sqrt{h}}\right)\left(1+26 \rho_{D}\right)
$$

and the shear capacity of cracked concrete is:

$$
\frac{\tau_{u}}{\tau_{c}}=11.64 \sqrt{\frac{\left(\omega_{s w}+\omega_{f w}\right)}{v_{0}}}
$$

with

$$
\tau_{c}=0.059 v_{0} f_{c}
$$

The upper-bound solution for the shear capacity of the cracked concrete taking into account finite stirrups spacing is given by:

$$
\frac{\tau_{u}}{\tau_{c}}=11.64 \sqrt{\frac{\left(\omega_{j w}+\omega_{f j}\right)}{v_{0}}}-16.95 \frac{\left(\omega_{s y}+\omega_{f w}\right)_{s}}{v_{0}} \frac{b}{b} \text { for } \frac{\left(\omega_{s w}+\omega_{f w}\right)}{v_{0}} \leq 0.21
$$

or

$$
\frac{\tau_{u}}{\tau_{c}}=2.67+16.95 \frac{\left(\omega_{s w}+\omega_{f w}\right)}{v_{0}}\left(0.75-\frac{s}{b}\right) \text { for } \frac{\left(\omega_{s w}+\omega_{f w}\right)}{v_{0}}>0.21
$$

The distance $x$ in original paper [10] is given by equation 9 , and the proposed in this paper is given by equation 10 :

$x=h \sqrt{\frac{2 \tau_{c}}{\omega_{s w} f_{c}}}$
$x=h \sqrt{\frac{2 \tau_{c}}{\left(\omega_{s w}+\omega_{f w}\right) f_{c}}}$

The angle of idealized diagonal crack $\theta_{\mathrm{CIN}}$ is given by:

$$
\operatorname{tg} \theta_{C I N}=\frac{h}{x}
$$

The equations $1,2,3,4,5,6,7,8,9,10$ and 11 indicate that the effectiveness factor $v_{0}$ is an important parameter in this theoretical formulation. It governs the concrete shear resistance and transverse reinforcement contributions for shear capacity. A rational choice of one adequate expression for this parameter is fundamental for the predicted results. The value of the effectiveness factor depends on the material, size effect, geometry, reinforcement, loading of the structures, and on the internal cracking process.

\subsection{Bond model}

The bond between carbon fiber composites and concrete is a fundamental hypothesis that requires special attention for it represents the means by which stress is transferred between concrete and CFC.

Significant advances in experimental studies into bond have been achieved in recent years, and research shows that this technique cannot mobilize the full tensile strength of CFC, due to the debonding and the peeling phenomenon.

The bond between CFC $U$ vertical stirrups and concrete is the key factor in this study. The proposed formulation adopts a bond model for the concrete-CFC interface, in which the CFC effective mechanical properties should be carefully analyzed. The theoretical model adopted is the debonding failure mode ([13]), and the effective axial CFC stress is given by:

$$
f_{f, e f}=E_{f} \varepsilon_{f, e f}
$$




\section{Figure 3 - Geometry of test beams}
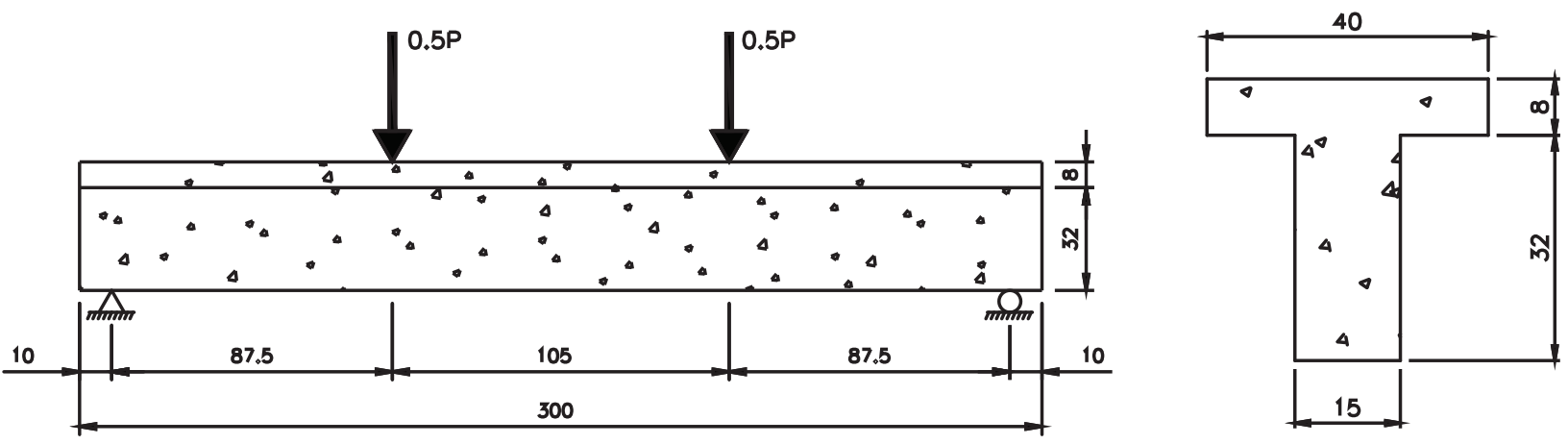

The effective stress has a non-uniform distribution, and at ultimate state is defined as:

$$
f_{f, e f}=D_{f} \sigma_{f, \max }
$$

$$
D_{f}=\frac{2}{\pi \lambda}\left(\frac{1-\cos \frac{\pi}{2} \lambda}{\sin \frac{\pi}{2} \lambda}\right)
$$

and the maximum stress is given by

$$
\sigma_{f, \max }=0.427 \beta_{w} \beta_{L} \sqrt{\frac{E_{f}}{t_{f}} \sqrt{f_{c}}} \leq f_{f, u}
$$

with

$$
\beta_{w}=\sqrt{\frac{2-\frac{w_{f}}{s_{f} \sin \beta}}{1+\frac{w_{f}}{s_{f} \sin \beta}}}
$$

$$
L_{e}=\sqrt{\frac{E_{f} t_{f}}{\sqrt{f_{c}}}}
$$

$$
\lambda=\frac{L_{\max }}{L_{e}}
$$

$$
\beta_{L}=\sin \frac{\pi \lambda}{2}
$$

\section{Experimental investigation}

\subsection{Test specimens}

Eight T reinforced concrete beams $3.00 \mathrm{~m}$ long were tested ([14]). All the specimens were designed to have the same nominal cross sectional dimensions: $b_{w}=15 \mathrm{~cm}$ and $h=40 \mathrm{~cm}$. Cross-sectional details of the beams are shown in Figure [3]. The specimens were also designed to be tested with a constant ratio $a / d=87.5 / 36=2.4$. The testing program was divided into two series with four beams tested as part of each series. In each series, one beam had no CFC reinforcement (reference beam), but the internal steel reinforcement was the same as that of the beams in the series. Specimens were labeled by the explanatory label: 1) Series I was one reference beam VR1 and three strengthened beams with $\mathbf{U}$ stirrups, with either one, two or three layers of CFC, VI-1, VI-2, VI-3, respectively; and 2) Series II was one reference beam VR2 and three strengthened beams with $\mathrm{U}$ stirrups, with either one, two or three layers of CFC, VII-1, VII-2 e VII-3, respectively. Series II had fewer internal steel stirrups in the midspan of the beam (bending zone) than Series I.

All CFC U stirrups $10 \mathrm{~cm} \times 79 \mathrm{~cm}$ were glued on to concrete surface, and a $5 \mathrm{~cm} \times 87.5 \mathrm{~cm}$ longitudinal strip (one layer of CFC) was fixed to the ends of the stirrup on both sides of the beams, as shown in Figures [4] and [5].

The beams in each series were cast simultaneously from the same batch of concrete, and consolidated with internal vibrators.

Table [1] presents a summary of the properties of the steel reinforcement (transverse reinforcement ratio), including the thickness, width and transverse ratio of the CFC reinforcement (variables of this research). Details of the beams are presented in Figure [6]. To prevent premature localized failure (anchorage failure), both ends of the beams were heavily reinforced and longitudinal bars were carefully anchored. 


\section{Figure 4 - Layout of the stirrups and longitudinal strip of CFC ( in $\mathrm{cm}$ )}

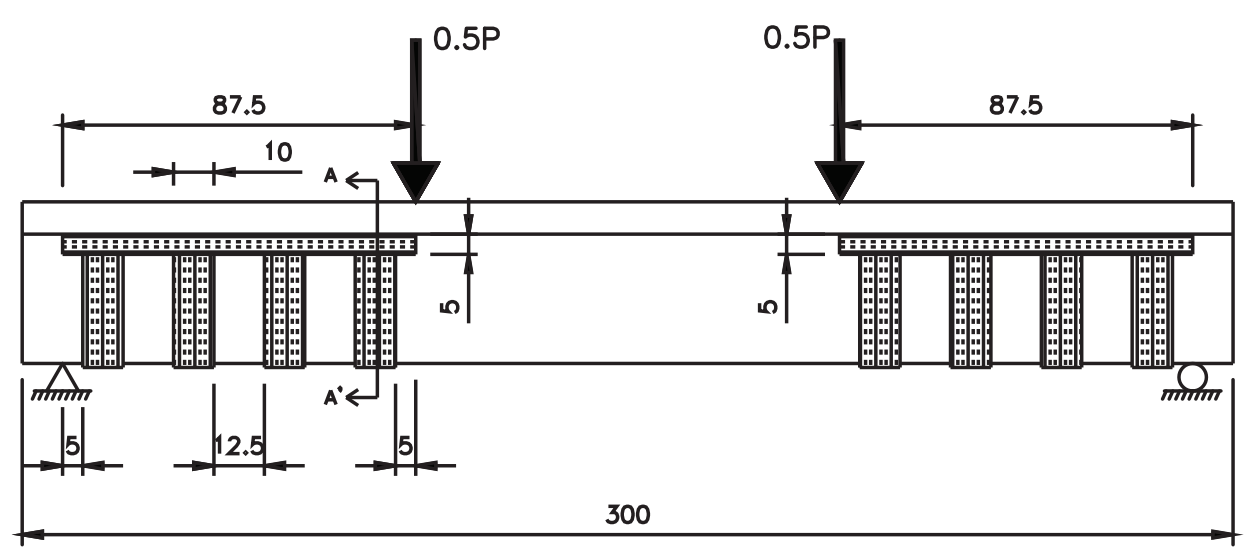

The steel transverse and longitudinal ratios are given by:

$$
\rho_{s w}=\frac{A_{s w}}{b_{w} s}
$$

$$
\rho_{s \ell}=\frac{A_{s \ell}}{b_{w} d}
$$

and the transverse CFC reinforcement is:

$$
\rho_{f}=\frac{2 t_{f} w_{f}}{b_{w} s_{f}}
$$

\subsection{Instrumentation}

Prior to casting the concrete, the strain gauges were attached to the steel reinforcements to obtain strain profile along these reinforcements (Figures [7] and [8]). Strain gauge rosettes with different angles were glued on to the concrete surface (Figure [9]) to obtain the two principal strains and the inclination angle of the main compressive strain with horizontal axis. The CFC $\mathbf{U}$ stirrups were instrumented with strain gauges in four different locations (Figure [10]).

A data logger was used to read and record the values given by the strain gauges, load cells, and linear variable displacement transducers (LVTDs).

\subsection{Materials}

A commercial concrete supplier delivered all the concrete used in the experimental program.
Following the cast, the beams were cured without special techniques and stored in laboratory conditions until the moment of testing. The cylinders used to establish the compressive strength and the modulus of elasticity of the concrete were cured under the

Figure 5 - External CFC $U$ stirrups of beams: a) VI-I and VII-1; b) VI-2 and VII-2; c) VI-3 and VII-3

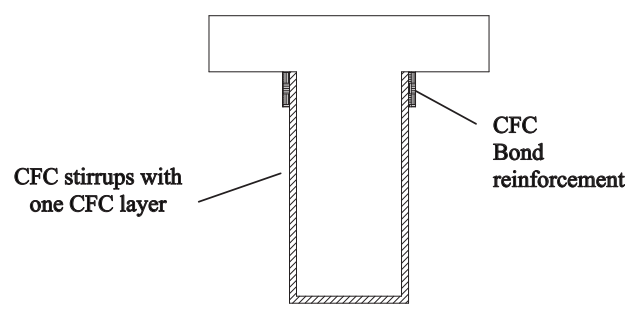

(a)

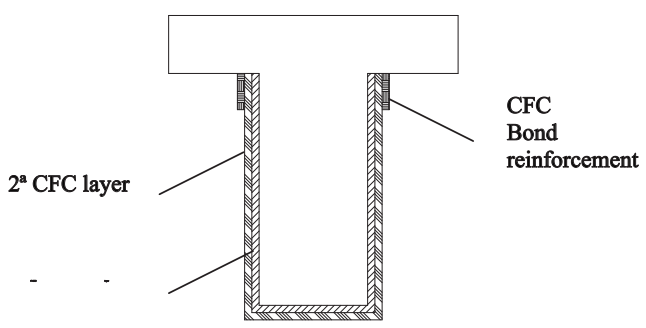

(b)

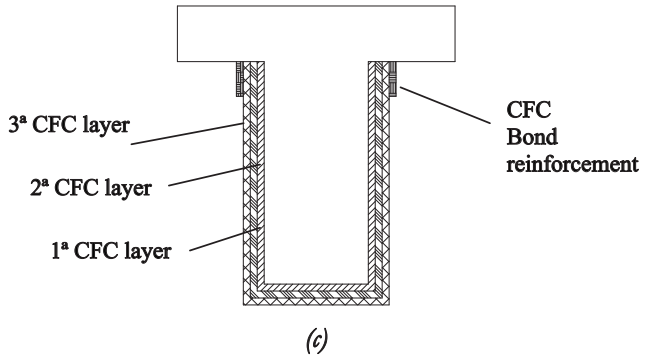


Table 1 - Reinforcement properties of the test beams

\begin{tabular}{|c|c|c|c|c|c|c|c|}
\hline Beam & $\begin{array}{l}\rho_{\mathrm{sw}} \\
(\%)\end{array}$ & $\omega_{\mathrm{sw}}$ & $\begin{array}{c}t_{f} \\
(\mathrm{~mm})\end{array}$ & $\begin{array}{c}\mathbf{s}_{\mathbf{1}} \\
(\mathrm{mm})\end{array}$ & $\begin{array}{c}\mathbf{w}_{1} \\
(\mathrm{~mm})\end{array}$ & $\begin{array}{l}\rho_{\mathrm{tw}} \\
(\%)\end{array}$ & $\omega_{t w}$ \\
\hline VR1 & 0.262 & 0.032 & - & - & - & - & 0 \\
\hline VI-1 & 0.262 & 0.030 & 0.122 & 225 & 100 & 0.072 & 0.022 \\
\hline VI-2 & 0.262 & 0.030 & 0.244 & 225 & 100 & 0.145 & 0.029 \\
\hline VI-3 & 0.262 & 0.030 & 0.366 & 225 & 100 & 0.217 & 0.034 \\
\hline VR2 & 0.131 & 0.016 & - & - & - & - & 0 \\
\hline VIII-1 & 0.131 & 0.015 & 0.122 & 225 & 100 & 0.072 & 0.022 \\
\hline VII-2 & 0.131 & 0.015 & 0.244 & 225 & 100 & 0.145 & 0.029 \\
\hline VIII-3 & 0.131 & 0.015 & 0.366 & 225 & 100 & 0.217 & 0.034 \\
\hline
\end{tabular}

Figure 6 - Configuration of steel reinforcements of series I and series II

$2 \mathrm{~N} 2 \oplus 5.0 \mathrm{C}=297$
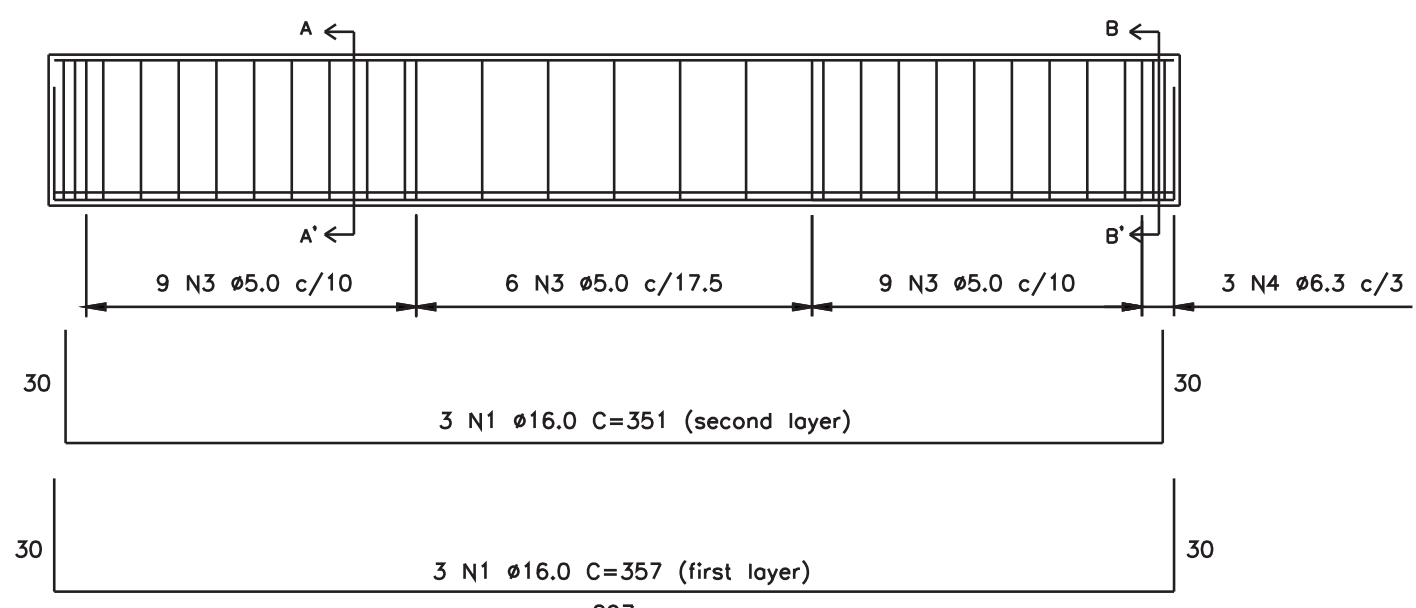

297

Figure 7 - General view of strain gauge locations on steel stirrups and longitudinal bar of series I
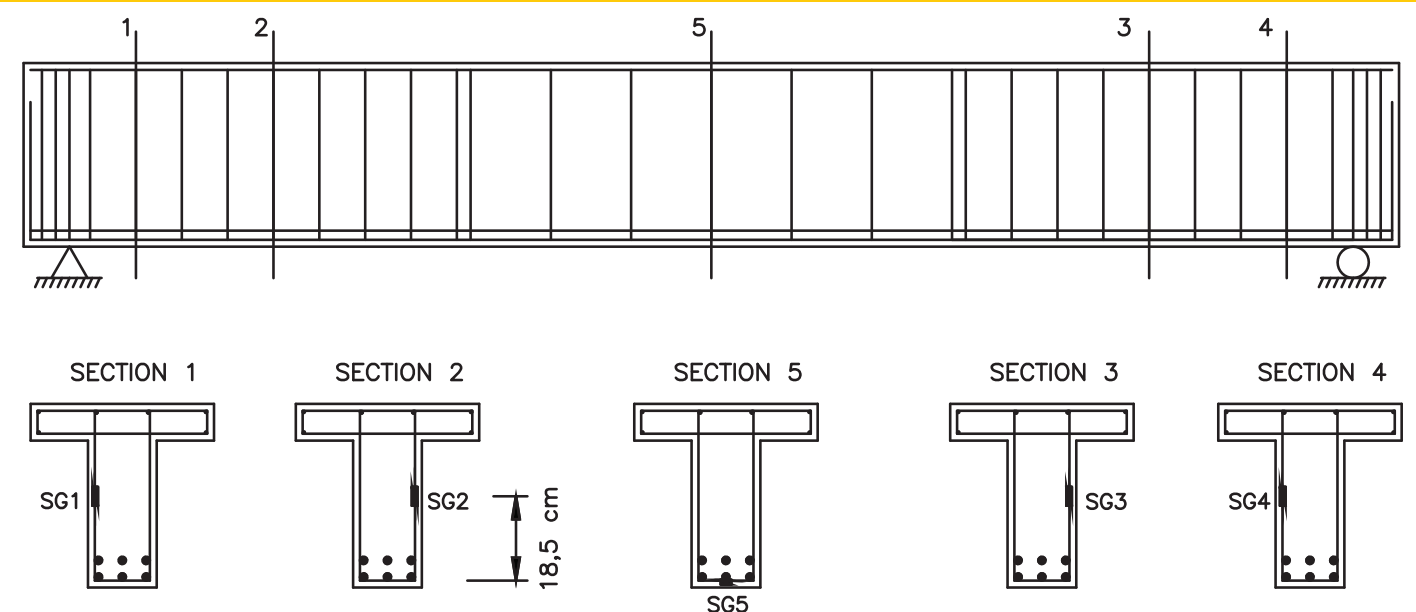
Figure 8 - General view of strain gauge locations on steel stirrups and longitudinal bars of series II, distance from support: section $1=0.15 \mathrm{~cm}$, section $2=0.45 \mathrm{~cm}$; section $5=$ middle and other sections are symmetric
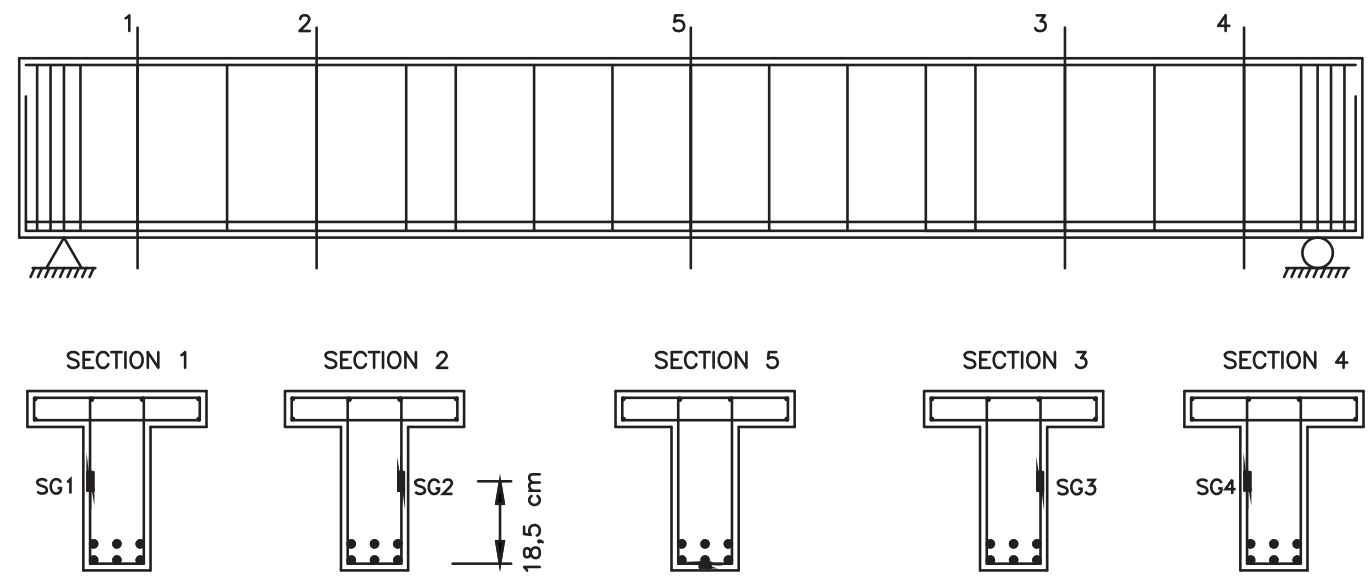

SECTION 2

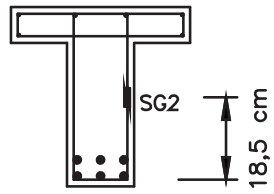

SECTION 5

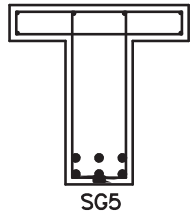

SECTION 3

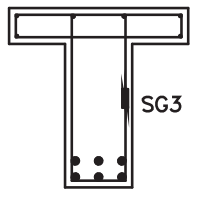

SECTION 4

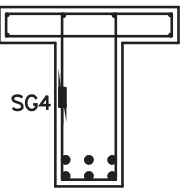

Figure 9 - Strain gauge rosette locations on concrete surface

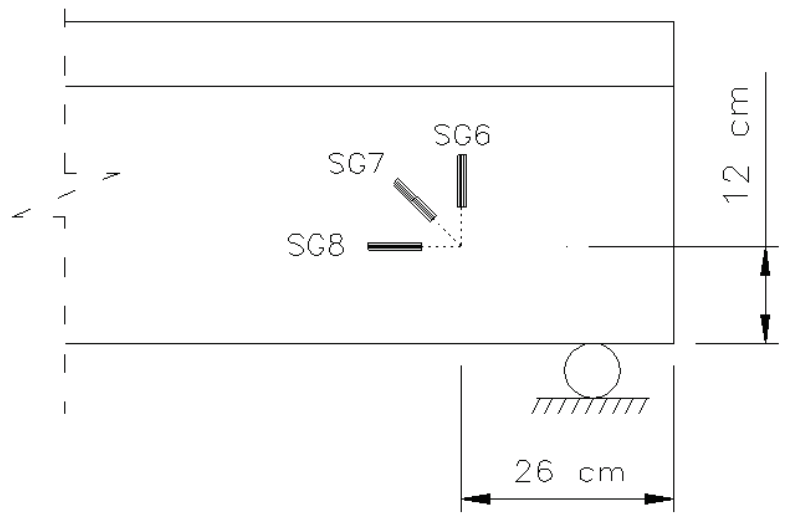

Beams VR1 and VR2

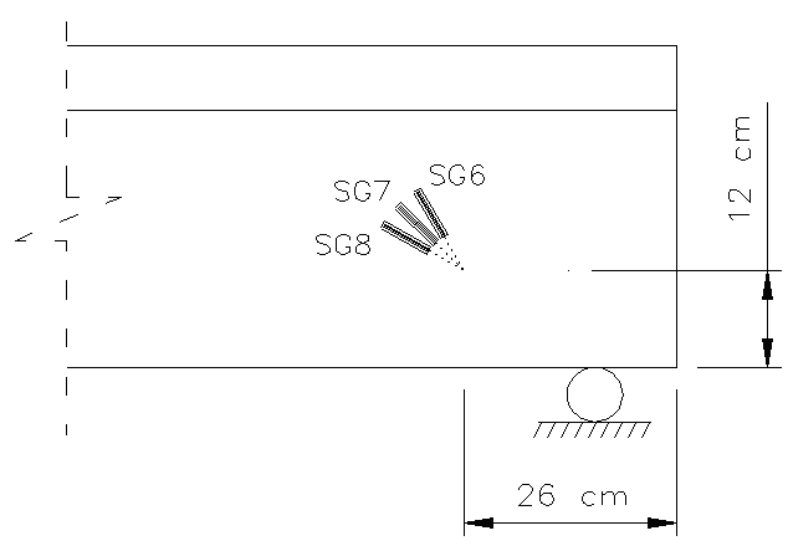

B Beams VI-1, VI-2, VI-3, VII-1, VII-2 and VII-3 same conditions as the beams. The ends of the cylinders were grounded before the tests. The cylinders were cast simultaneously with beams using the same batch concrete. The average value of the compressive strength of the concrete for each test beam was obtained from three $15 \mathrm{~cm} \times 30 \mathrm{~cm}$ cylinder specimens. Table [2] shows the concrete strength. All the specimens were tested in accordance with Brazilian standards. The average concrete secant modulus is $25.01 \mathrm{GPa}$, and the average splitting stress (Brazilian test) is $4.08 \mathrm{MPa}$.

The ordinary steel bars were ribbed bars with diameters of 5 $\mathrm{mm}, 8 \mathrm{~mm}$, and $16 \mathrm{~mm}$. Tensile tests on three representative specimens of each reinforcing bar type were conducted. The average values of the yield stress and yield strain were $596 \mathrm{MPa}$ and $0.30 \%$ for $5 \mathrm{~mm}$ diameter, and $600 \mathrm{MPa}$ and $0.20 \%$ for 16 $\mathrm{mm}$ diameter, respectively. The $8 \mathrm{~mm}$ bars were not considered in the design because this reinforcement was only a support for the steel stirrups.

The CFC was tested in accordance with ASTM D3039/D3039M ([15]); CFC mechanical properties (mean values) was: tensile strength $2969 \mathrm{MPa}$, ultimate strain $11.6 \%$, modulus of elasticity 255.000 MPa.

\subsection{Test setup and loading procedures}

All eight $\mathbf{T}$ reinforced concrete beams were tested on steel frames with capacities of $500 \mathrm{kN}$ and $1000 \mathrm{kN}$, fixed on the plate reactor of the Laboratory of Structures of PUC-Rio. The applied force was measured using a load cell in series with an actuator. Beams were loaded at two points with force control using a double action hydraulic actuator located at the top of the supplementary steel beam.

The beams VR1 and VR2 were tested with a monotonic loading until failure, and the beams VI-1, VI-2, VI-3, VII-1, VII-2, and VII-3 were loaded under sustained strain with a special apparatus after bending cracking (after the first crack) and strengthening. They were subsequently loaded monotonically until failure.

The load was applied in imposed deformation steps by a hydraulic jack, and was controlled by load cells placed at the beam supports. The load cell under the jack furnished the ultimate load $P_{u \text { exp }}$. 
Figure 10 - General view of strain gauge locations on CFC $U$ stirrups of all strengthened beam, distance from support: section $12=0.33 \mathrm{~cm}$; section $13=0.55 \mathrm{~cm}$; the other sections are symmetric
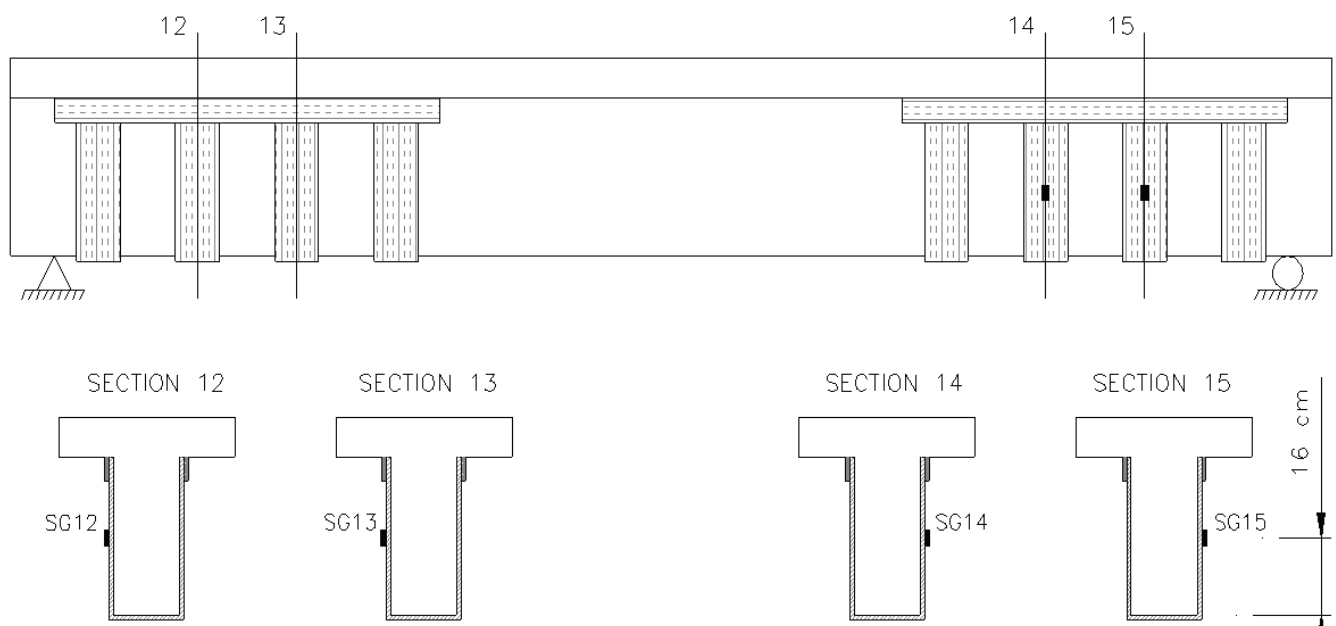

SECTION 13
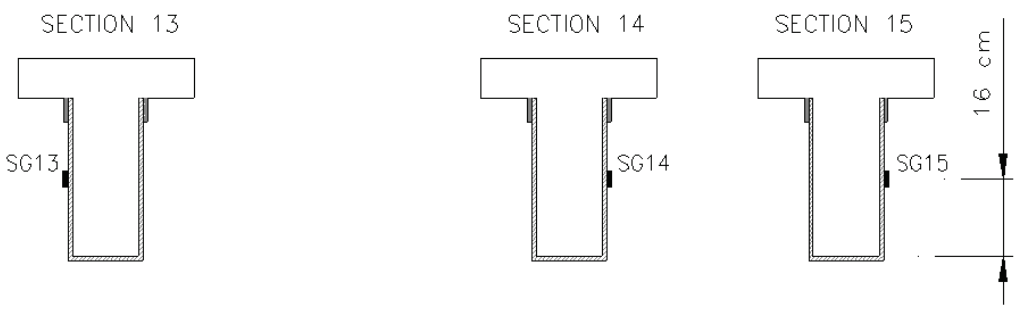

\begin{tabular}{|cccc|}
\hline Table 2 & - Concrete compressive strength \\
\hline Becm & $\begin{array}{c}\text { Cylindrical } \\
\text { Specimens }\end{array}$ & $\begin{array}{c}\text { Concrete } \\
\text { age (days) }\end{array}$ & $\begin{array}{c}f_{\text {c,average }} \\
\text { (MPa) }\end{array}$ \\
\hline- & 4 & 28 & 44.90 \\
VR1 & 3 & 48 & 48.44 \\
VR2 & 3 & 57 & 49.92 \\
VII-1 & 3 & 153 & 50.94 \\
VII-2, VI-1, VI-2 & 3 & 216 & 51.73 \\
VII-3, VI-3 & 3 & 335 & 52.30 \\
\hline
\end{tabular}

\subsection{Failure}

For the beam with no descending branch, the authors considered the ultimate load as equal to the maximum load.

The reference beams in the experimental program failed by diagonal tension, and the strengthened beams failed by diagonal tension with simultaneous debonding of the CFC stirrups (Table [3]). Failure of the beams occurred after the steel stirrup yielded and started to present an inclined shear crack that grew in the direction of the beam flange. Bending or anchorage failure did not occur. Figure [11] shows the pattern of failure of beams VR2 and VII-1.

\section{Discussion of results}

\subsection{Analysis of strength}

The variables of the experimental program were concrete strength and mechanical ratio of CFC stirrups. The tests were conducted in reinforced concrete beams made of normal strength concrete.

\section{Experimental results}

\subsection{Cracking}

The data collected by the strain gauges and LVTDs was recorded using a special digital data acquisition system. During the test, the cracks developed-were marked without interruption of the load process. Flexural cracks at the midspan started from the bottom face and propagated vertically through the height of the beams. As the applied load increased and the internal stress was redistributed, several other secondary flexural cracks were observed, starting from the main bending cracks. The load cell under the jack furnished the cracking load $P_{C R}$. Table [3] shows that crack loads for VR1 and VR2 were of the same level, and that the crack loads for Series I were greater than those for Series II.

\subsection{Ductility}

All longitudinal reinforcement yielded, but not simultaneously with the steel stirrups. Table [3] shows that the steel stirrups of Series II did not yield. Nevertheless, it is possible to conclude that the beams tested in this research program presented good ductility. ing factor varied only with concrete strength since all beams had the same height and longitudinal reinforcement.

After the cracking tension, the strengthened beams experienced a sudden failure with the debonding and rupture of CFC $U$ stirrups.

The theoretical values of ultimate shear force $V_{u}$ theor were calculated by considering the bond between the CFC $U$ stirrups and concrete to be perfect, which was verified by the theoretical approach shown in this paper.

The load of the strengthened beams was $36 \%$ to $54 \%$ greater than that of the reference beams. As presented in the penultimate column of Table [3], the mean strength ratio is $V_{u, \exp } / V_{u, r e f}=1.43$ with a coefficient of variation of $4.41 \%$. This shows that the shear strength of all the beams increased substantially, and that all the arrangements of the CFC $U$ stirrups studied are effective for shear reinforcement.

\subsection{Angles}

Using all the relevant images of the cracking of the beams and with the aid of a computer program, digital procedures were used to obtain the crack angle $\theta_{\mathrm{CR}}$ (Figure [12]). 
Figure 11 - Beam failure: a) VR2; b) VII-1

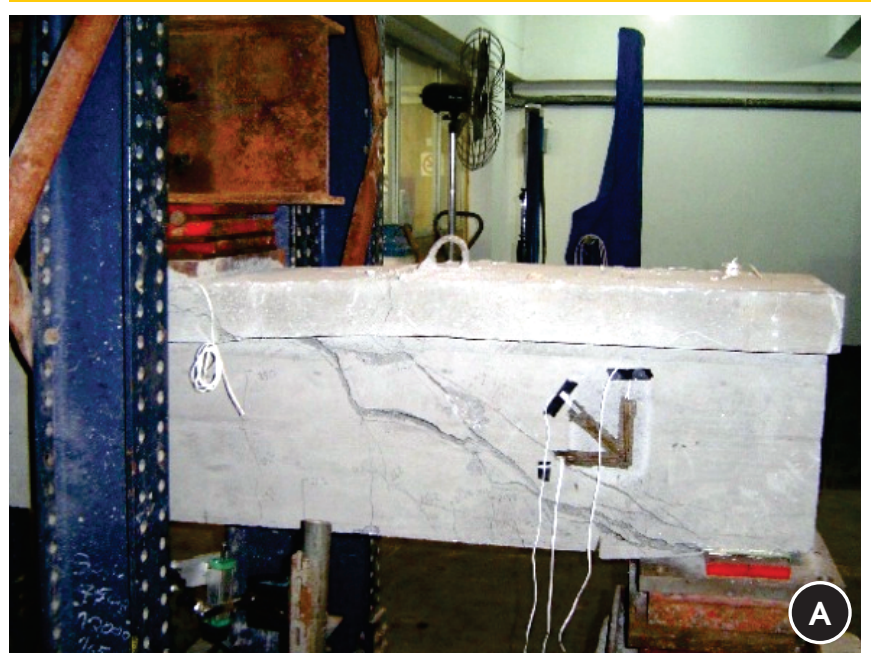

The deformation field angle $\theta_{\varepsilon}$ was obtained by classical formulas of Solids Mechanics, with the aid of readings of the strain gauge rosettes. The basic hypothesis of the CSM is evaluated by means of comparing the crack angle $\theta_{C R}$, the deformation field angle $\theta_{\varepsilon}$, and the angle of idealized diagonal crack sliding $\theta_{C I N}$ because the yield line is assumed to be equal to the crack in this model. This shows that this model furnishes good agreement with the experimental data of this test program. The suitability of this theoretical model can also be assessed by analysis of the ratios $\theta_{C R} / \theta_{C I N}$ and $\theta_{\varepsilon} / \theta_{C I N}$, which gives good statistical results.

Table [4] shows the different types of angle measured in tests, the crack angle $\theta_{C R}$, the deformation field angle $\theta_{\varepsilon}$ and the theoretical values for the ultimate shear given by the CSM $\theta_{C I N}$. The calculated shear theoretical capacity is not limited by the bond model

\section{Figure 12 - Crack angle in the shear span of VR1 (digital measurement)}

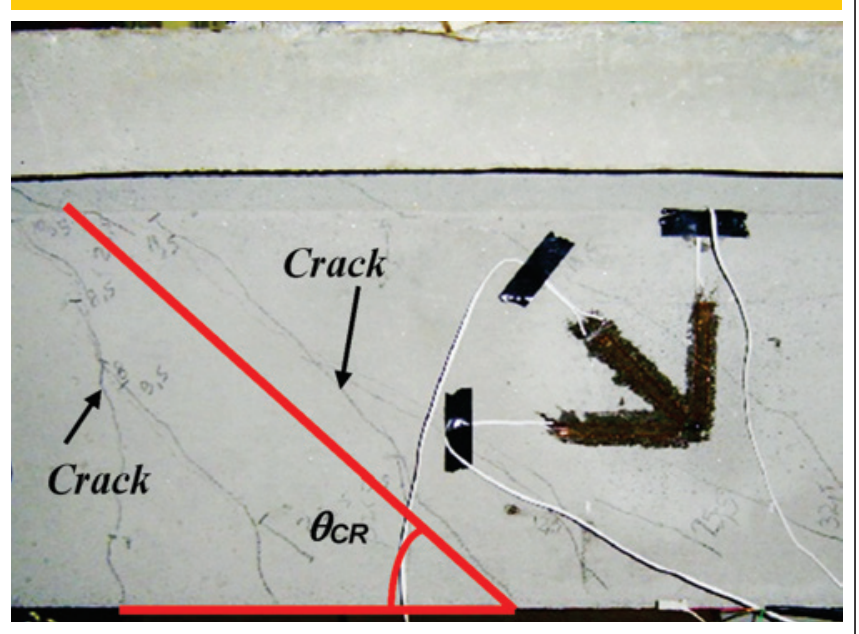

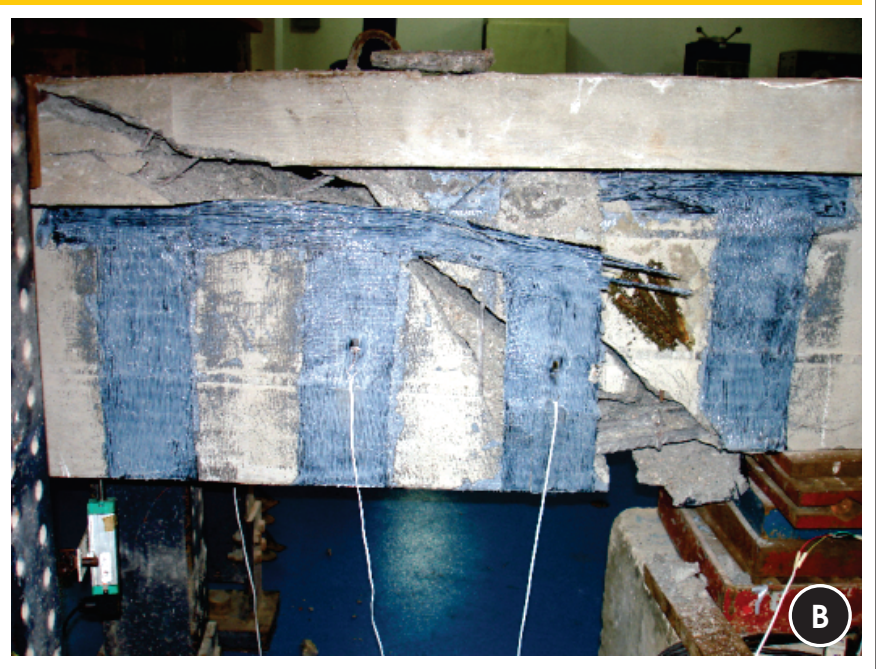

adopted. As shown in the last column, the mean strength ratio is $V_{u, \text { exp }} / V_{u \text {,theor. }}=1.07$ with a coefficient of variation of $6.79 \%$.

\subsection{Comparison between experimental data and upper-bound solution}

The ultimate theoretical shear strength of each beam was computed using equations 1 to 19 , as discussed earlier. The predictions of the CSM are very close to the test beam results.

A very good agreement is obtained in terms of strength, but additional study into this theoretical approach is necessary, focusing on different reinforcement ratios and other stirrup-configurations.

\section{Conclusions}

The results confirm that the technique of strengthening with CFC sheets significantly increases shear capacity. None of the beams presented bending failure, and the ultimate load of the strengthened beams was $36 \%$ to $54 \%$ greater than the reference beams. All the beams showed good ductile behavior.

The CFC strips glued on top of CFC $\mathbf{U}$ stirrups are an effective way of guaranteeing the bond between the CFC and the concrete surface.

The proposed upper-bound model provides good results and the ratio $V_{u \text { exp }} / V_{u \text {,theor. }}$ has a coefficient of variation of $6.79 \%$, but the following considerations should be made:

- the theoretical results depend on the values assumed by the concrete effectiveness factor, i.e., the adoption of an appropriate expression for $v_{0}$ governs the results;

- the equation $\omega=\omega_{s w}+\omega_{f w}$ is susceptible to criticism, because the CFC external stirrups do not have the same mechanical behavior as the steel stirrups, due, mainly, to the fact that they are not completely enveloped by the concrete or provide a dowel action. The assumption that the total shear strength is the sum of the steel and CFC reinforcement strengths (i.e., the additive approach for reinforcements) is the fundamental hypothesis for all theoretical models. 
The angles $\theta_{C R}, \theta_{\varepsilon}, \theta_{C I N}$ are very similar, and the low coefficient

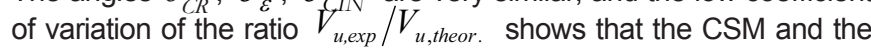
bond model presented form a consistent approach to study the shear strengthening of reinforced concrete beams with CFC U stirrups.

Due to a limited number of available experimental results, the authors' opinion is that it is premature to corroborate the CSM as a consistent and valid approach to the design of CFC stirrups for reinforced concrete beams. The research methodology presented only indicates that new theoretical approaches to this field should be taken into account. Research in this area must continue with more tests to obtain the accurate theoretical model and provisions for the design of shear strengthening.

\begin{tabular}{|c|c|c|c|c|c|c|c|c|c|c|c|}
\hline \multicolumn{12}{|c|}{ Table 3 - Test results } \\
\hline \multirow[b]{2}{*}{ Beam } & \multirow[b]{2}{*}{$\begin{array}{c}f_{o} \\
(k N)\end{array}$} & \multirow[b]{2}{*}{$\begin{array}{l}\text { CFC } \\
\text { layer }\end{array}$} & \multirow[b]{2}{*}{$\begin{array}{l}\mathbf{P}_{\mathrm{CR}} \\
(\mathbf{k N})\end{array}$} & \multicolumn{3}{|c|}{ Ultimate strain (\%) } & \multirow{2}{*}{$\begin{array}{c}\text { Maximum } \\
\text { deflection } \\
\text { (mm) } \\
\text { LVDT } 2\end{array}$} & \multirow[b]{2}{*}{$\begin{array}{l}P_{u, \text { exp }} \\
(\mathbf{k N})\end{array}$} & \multirow[b]{2}{*}{$\begin{array}{l}\mathbf{V}_{\mathrm{u}, \mathrm{exp}} \\
(\mathbf{k N N})\end{array}$} & \multirow[b]{2}{*}{$\frac{\mathbf{V}_{\mathrm{u}, \mathrm{exp}}}{\mathbf{V}_{\mathrm{u}, \text { ref }}}$} & \multirow[b]{2}{*}{$\begin{array}{c}\text { Failure } \\
\text { type }\end{array}$} \\
\hline & & & & $\begin{array}{r}\text { St } \\
\text { Long. }\end{array}$ & $\begin{array}{l}\text { el } \\
\text { Transv. }\end{array}$ & $\begin{array}{l}\text { CFC } \\
\text { stirrup }\end{array}$ & & & & & \\
\hline VR1 & 48.44 & - & 70.00 & 2.87 & 5.51 & - & 13.05 & 407.22 & 203.61 & - & DT \\
\hline VI-1 & 51.73 & 1 & 165.41 & 4.21 & 4.25 & 7.40 & 19.19 & 552.79 & 276.40 & 1.36 & DTD \\
\hline $\mathrm{Vl}-2$ & 51.73 & 2 & 166.97 & 4.58 & 6.71 & 4.75 & 17.91 & 586.65 & 293.33 & 1.44 & DTD \\
\hline VI-3 & 52.30 & 3 & 168.55 & 3.71 & 7.46 & 4.53 & 17.28 & 590.13 & 295.07 & 1.45 & DTD \\
\hline VR2 & 49.92 & - & 65.00 & 2.24 & 0.86 & - & 12.89 & 302.50 & 151.25 & - & DT \\
\hline VII-1 & 50.94 & 1 & 111.68 & 2.06 & 1.55 & 2.08 & 12.52 & 433.34 & 216.67 & 1.43 & DTD \\
\hline VII-2 & 51.73 & 2 & 135.37 & 2.72 & 1.63 & 5.46 & 12.60 & 466.57 & 233.29 & 1.54 & DTD \\
\hline \multirow[t]{5}{*}{ VII-3 } & 52.30 & 3 & 140.34 & 2.60 & 0.75 & 4.43 & 13.31 & 416.30 & 208.15 & 1.38 & DTD \\
\hline & & & & & & \multicolumn{3}{|c|}{ Average } & & \multicolumn{2}{|l|}{1.43} \\
\hline & & & & & & \multicolumn{3}{|c|}{ Standard deviation } & & \multicolumn{2}{|l|}{0.06} \\
\hline & & & & & & \multicolumn{3}{|c|}{ Coefficient of variation (\%) } & & \multicolumn{2}{|l|}{4.41} \\
\hline & & & & & \multicolumn{7}{|c|}{$\begin{array}{l}\text { DT= diagonal tension; DTD= diagonal tension with CFC debonding } \\
\text { (in this order). }\end{array}$} \\
\hline
\end{tabular}

\section{Table 4 - Test beams data}

\begin{tabular}{|c|c|c|c|c|c|c|c|c|}
\hline Beam & $\theta_{\mathrm{CR}}\left({ }^{\circ}\right)$ & $\theta_{0}\left({ }^{\circ}\right)$ & $\theta_{\mathrm{cIN}}\left({ }^{\circ}\right)$ & $\begin{array}{l}\mathbf{V}_{\mathrm{u}, \mathrm{exp}} \\
(\mathrm{kN})\end{array}$ & $\begin{array}{l}V_{u, \text { theor }} \\
(\mathrm{kN})\end{array}$ & $\frac{\theta_{\mathrm{CR}}}{\theta_{\mathrm{CIN}}}$ & $\frac{\theta_{\mathrm{e}}}{\theta_{\mathrm{CIN}}}$ & $\frac{\mathbf{V}_{\mathrm{u}, \mathrm{exp}}}{\mathbf{V}_{\mathrm{u}, \mathrm{h} \text { hoor }}}$ \\
\hline VI-1 & 39 & 33.63 & 43.06 & 276.40 & 250.07 & 0.91 & 0.78 & 1.11 \\
\hline VI-2 & 41 & 40.04 & 45.00 & 293.33 & 259.83 & 0.91 & 0.89 & 1.13 \\
\hline VI-3 & 42 & 41.38 & 46.16 & 295.07 & 266.85 & 0.91 & 0.90 & 1.11 \\
\hline VIII-1 & 38 & 44.97 & 38.30 & 216.67 & 201.00 & 0.99 & 1.17 & 1.08 \\
\hline VII-2 & 40 & 41.93 & 40.82 & 233.29 & 215.43 & 0.98 & 1.11 & 1.08 \\
\hline VII-3 & 39 & 43.75 & 42.36 & 208.15 & 224.49 & 0.92 & 1.03 & 0.93 \\
\hline \multicolumn{6}{|c|}{ Average } & 0.94 & 0.98 & 1.07 \\
\hline \multicolumn{6}{|c|}{ Standard deviation } & 0.04 & 0.15 & 0.07 \\
\hline \multicolumn{6}{|c|}{ Coefficient of variation (\%) } & 4.21 & 15.14 & 6.79 \\
\hline $\mathrm{VR} 1^{*}$ & 40 & 30.37 & 35.94 & 203.61 & 207.64 & 1.11 & 0.85 & 0.98 \\
\hline VR2* & 34 & $\star *$ & 26.96 & 151.25 & 141.98 & 1.26 & - & 1.07 \\
\hline
\end{tabular}


The theoretical results for the beams with inclined stirrups should be carefully analyzed in the future because the original upperbound model was formulated for vertical stirrups only.

Finally, it is necessary to verify the proposed model comparing the theoretical results with more experimental data, as well as adopt other expressions for the concrete effectiveness factor.

\section{References}

[01] American Concrete Institute - ACI 318. Building code requirements for structural concrete. USA. 2005.

[02] American Concrete Institute - $\mathrm{ACl} 440$. Guide for the design and construction of the externally bonded FRP systems for strengthening concrete structures. USA. 2001.

[03] FIB (CEB-FIP). Externally bonded FRP reinforcement for RC structures. Bulletin 14. Lausanne. 2010.

[04] SIKA - Electronic catalogue, www.sika.com.br; visited in 2006.

[05] SALLES NETO, M. Shear behavior of reinforced concrete $T$ beams strengthening with carbon fiber composites (in Portuguese). M.Sc. Dissertation. UnB. Brazil. 2000.

[06] JAYAPRAKASH, J.; SAMAD, A. A. A.; ALI, A. A. A.; ABBASOVICH, A. A. An experimental investigation on shear enhancement cracked RC beams with bi-directional carbon fabrics. Cement Combination for Durable Concrete, Thomas Telford. UK. 2005. pp.537-546.

[07] BEBER, A. Structural behavior of reinforced concrete beams strengthening with carbon fiber composites (in Portuguese). PhD Thesis. UFRGS. Brazil. 2003.

[08] KHALIFA, A.; NANNI, A. Rehabilitation of rectangular simply supported RC beams with shear deficiencies using CFRP composites. Constructions and Building Materials, Vol. 6, No 3. 2002.

[09] ADHIKARY, B. B.; MUTSUYOSHI, H.; ASHRAF, $M$. Shear strengthening of $R C$ beams using FRP sheets with bonded anchorage. ACI Structural Journal. Vol. 1001, No 5. 2004. p.660-668.

[10] HOANG, L. C. Shear strength of non-shear reinforced concrete elements. Department of Structural Engineering and Materials. Technical University of Denmark, Report No 29. 1997.

[11] HOANG, L. C.; NIELSEN, M. P. Plasticity approach to shear design. Cement and Concrete Composites, 20. 1998. p.437-453.

[12] NIELSEN, M. P. Limit analysis and concrete plasticity. CRC Press. USA. 1999.

[13] CHEN, J. F.; TENG, J. G. Shear capacity of FRP-strengthened RC beams: FRP debonding. Construction and Building Materials, 17. 2003. p.27-41.

[14] SPAGNOLO JUNIOR, L. A. Experimental study of reinforced concrete beams strengthened for shear force with carbon fiber composites. Master Science Dissertation (in Portuguese). PUC-Rio. 2008.

[15] American Society for Testing and Materials - ASTM D3039/D3039M. Standard test method for tensile properties of polymer matrix composite materials. USA. 2000.

\section{Notation}

$$
\begin{aligned}
& a \quad=\text { shear } \operatorname{span} \\
& A_{f \ell}=\text { CFC longitudinal area } \\
& A_{f t}=\text { CFC transverse area } \\
& A_{s w}=\text { total cross sectional area of steel stirrups in web } \\
& b \quad=\text { flange width } \\
& b_{w} \quad=\text { web width of beam } \\
& d \quad=\text { effective deep of beam } \\
& D_{f} \quad=\text { stress distribution factor } \\
& E_{f} \quad=\text { CFC elastic modulus } \\
& f_{c}=\text { uniaxial standard compressive strength of concrete } \\
& f_{f} \quad=\text { CFC tension } \\
& f_{f, e f}=\text { effective axial CFC stress } \\
& f_{t, e f}=\text { effective tensile strength of concrete } \\
& f_{f, u}=\text { CFC ultimate tensile strength } \\
& f_{s} \quad=\text { steel tension } \\
& f_{y w} \quad=\text { yield steel strength } \\
& \text { b = depth of beam } \\
& L_{e} \quad=\text { effective bond length } \\
& L_{\max }=\text { maximum bond length } \\
& P \quad=\text { applied load } \\
& P_{C R}=\text { crack load } \\
& P_{u, \exp }=\text { experimental ultimate load } \\
& s \quad=\text { steel stirrup spacing } \\
& s_{f} \quad=\text { CFC stirrup spacing } \\
& t_{f}=\text { CFC thickness } \\
& u=\text { displacement } \\
& V \quad=\text { shear force } \\
& V_{c} \quad=\text { concrete shear contribution } \\
& V_{u, \exp }=\text { ultimate shear strength } \\
& V_{u, r e f}=\text { ultimate shear strength of reference beam } \\
& V_{u, t h e o r}=\text { ultimate theoretical shear strength } \\
& w_{f} \quad=\text { stirrup width } \\
& x=\text { horizontal projections of yield line/critical diagonal crack } \\
& \alpha \quad=\text { angle between yield line and displacement direction } \\
& \beta=\text { angle of the CFC stirrup with horizontal axis } \\
& \beta_{L} \quad=\text { non-dimensional coefficient } \\
& \beta_{w} \quad=\text { non-dimensional coefficient } \\
& \varepsilon_{f, e f}=\text { CFC effective strain }
\end{aligned}
$$

